\title{
KOMPETENSI SUMBER DAYA MANUSIA DAN PENERAPAN SISTEM PENGENDALIAN INTERN PEMERINTAH TERHADAP KUALITAS LAPORAN KEUANGAN
}

\author{
Devi Lusiyana $^{1}$, Arik Susbiyani ${ }^{2}$, Didik Eko ${ }^{3}$ \\ Universitas Muhammadiyah Jember ${ }^{1,2,3}$ \\ devi2020123@gmail.com ${ }^{1}$
}

\begin{abstract}
ABSTRAK
Tujuan penelitian ini adalah untuk mengetahui apakah kompetensi Sumber Daya Manusia (SDM) dan penerapan sistem pengendalian intern pemerintah (SPIP) berpengaruh signifikan terhadap kualitas Laporan Keuangan Pemerintah Daerah (LKPD). Metode yang digunakan pada penelitian ini yaitu metode survei melalui kuesioner sebagai alat penelitian yang disebar kepada 50 (responden) pegawai Badan Pengelola Keuangan dan Aset Daerah (BPKAD) Pemerintah Daerah Kabupaten Bondowoso dengan pemilihan sampel jenuh. Pengujian dilakukan menggunakan uji validitas dan reliabilitas. Hasil penelitian menunjukkan bahwa terdapat pengaruh antara kompetensi sumber daya manusia dan penerapan sistem pengendalian intern pemerintah terhadap kualitas laporan keuangan. Simpulan, kompetensi SDM berpengaruh secara signifikan terhadap kualitas LKPD dan penerapan SPIP mempunyai pengaruh signifikan terhadap kualitas LKPD.
\end{abstract}

Kata Kunci: Laporan Keuangan, Kompetensi Sumber Daya Manusia, Pemerintah Daerah, Sistem Pengendalian Intern Pemerintah

\section{ABSTRACT}

The purpose of this study was to determine whether the competence of Human Resources (HR) and the implementation of the government internal control system (SPIP) had a significant effect on the quality of Regional Government Financial Reports (LKPD). The method used in this research is a survey method through a questionnaire as a research tool which is distributed to 50 (respondents) employees of the Regional Financial and Asset Management Agency (BPKAD) of the Regional Government of Bondowoso Regency with saturated sample selection. Tests are carried out using validity and reliability tests. The results showed that there was an influence between human resource competence and the implementation of the government's internal control system on the quality of financial reports. In conclusion, HR competence has a significant effect on the quality of LKPD and the application of SPIP has a significant effect on the quality of LKPD.

Keywords: Financial Report, Human Resource Competence, Local Government, Government Internal Control System 


\section{PENDAHULUAN}

Laporan keuangan adalah catatan informasi keuangan suatu perusahaan/lembaga pemerintah pada suatu periode akuntansi yang dapat digunakan untuk menggambarkan kinerja perusahaan/lembaga tersebut. Laporan keuangan adalah bagian dari proses pelaporan keuangan. Laporan keuangan yang lengkap biasanya terdiri dari neraca laporan laba rugi komprehensif, laporan perubahan ekuitas, laporan perubahan posisi keuangan yang dapat disajikan berupa laporan arus kas dana, catatan dan laporan lain serta materi penjelasan yang merupakan bagian integral dari laporan keuangan. Informasi dalam laporan keuangan banyak digunakan oleh pihak-pihak yang berkepentingan untuk mengambil keputusan. Pemerintah daerah selaku pengelolaan dana harus mampu menyediakan informasi keuangan yang diperlukan secara akurat, relevan, tepat waktu dan dapat dipercaya dalam rangka mempertanggungjawabkan keuangan negara (Halim, 2012).

Laporan keuangan yang berkualitas dan dapat berjalan efektif membutuhkan sumber daya manusia yang memahami dan kompeten dalam akuntansi pemerintah keuangan daerah. Kualitas laporan keuangan daerah membutuhkan sistem pengendalian intern pemerintah dan sistem informasi akuntansi keuangan daerah sebagai kontrol dan rujukan untuk meningkatkan kualitas laporan keuangan(Wati et al., 2014).

Berdasarkan teori peningkatan kualitas laporan keuangan di atas, maka objek penelitian yang dipilih ialah pada Badan Pengelolaan Keuangan dan Aset Daerah Kabupaten Bondowoso. Berdasarkan UU Republik Indonesia Nomor 25 Tahun 2004, tentang sistem perencanaan pembangunan nasional mancakup landasan hukum dibidang perencanaan pembangunan baik pemerintah pusat maupun pemerintah daerah (Presiden Republik Indonesia, 2004). Di dalam UU tersebut ditetapkan bahwa sistem perencanaan pembangunan nasional adalah satu kesatuan tata cara perencanaan pembangunan dalam rangka menghasilkan rencana pembangunan dalam jangka panjang, menengah dan tahunan yang dilaksanakan oleh unsur pemerintah di pusat dan daerah dengan melibatkan masyarakat.

Berdasakan undang-undang mengenai peranan Badan Pengelolaan Keuangan dan Aset Daerah Kabupaten Bondowoso, maka dalam menjalankan fungsinya masih terdapat beberapa kendala mengenai kualitas laporan keuangan daerah yang di laksanakan oleh Badan Pengelolaan Keuangan dan aset Daerah Kabupaten Bondowoso. 
Maka isu-isu strategi yang perlu mendapat perhatian dan penanganan serius dalam pelaksanaan tugas pokok dan fungsi BPKAD untuk lima tahun ke depan terdiri dari: penyampaian Rencana Kerja dan Anggaran (RKA) dan laporan keuangan Organisasi Perangkat Daerah (OPD) tidak tepat waktu; regulasi keuangan yang selalu berubah; keterlambatan penyampaian Surat Pertanggungjawaban (SPJ) oleh OPD. Pada penelitian ini, peneliti mendapati kualitas laporan keuangan daerah Kabupaten Bondowoso masih belum sempurna. Oleh karena itu, peneliti mencoba mengangkat beberapa faktor yang diasumsikan penting dalam meningkatkan laporan keuangan terutama pada peningkatan mutu kerja sumber daya manusia seperti kompetensi sumber daya manusia dan penerapan sistem pengendalian intern pemerintah terhadap kualitas laporan keuangan pemerintah daerah.

\section{KAJIAN TEORI}

Kompetensi merupakan kemampuan menjalankan tugas atau pekerjaan dengan dilandasi oleh pengetahuan, keterampilan dan didukung oleh sikap yang menjadi karakteristik individu. Sumber daya manusia adalah pegawai yang siap, mampu dan siaga dalam mencapai tujuan-tujuan organisasi yang berhubungan dengan pengetahuan, keterampilan, kemampuan dan karakteristik kepribadian yang mempengaruhi secara langsung terhadap kinerjanya (Marwansyah, 2012).

\section{Faktor-Faktor yang Mempengaruhi Sumber Daya Manusia (SDM)}

Berikut merupakan faktor-faktor yang mempengaruhi SDM: 1) keyakinan dan nilai-nilai. Keyakinan tentang dirinya maupun terhadap orang lain akan sangat perilaku. Setiap orang harus berfikir positif baik tentang dirinya maupun terhadap orang lain dan menunjukkan ciri orang yang berfikir kedepan; 2) keterampilan, keterampilan berbicara di depan umum dan menulis, individu akan meningkatkan kecakapannya dalam kopentensi tentang perhatian terhadap komunikasi; 3) pengalaman, berupa pengalaman mengorganisasikan orang dan komunikasi di hadapan kelompok; 4) karakteristik kepribadian. Kepribadian termasuk banyak faktor yang sulit untuk berubah akan tetapi, kepribadian bukan suatu yang tidak dapat berubah kenyataanya, kepribadian seseorang dapat berubah sepanjang waktu orang merespon dan berinteraksi dengan kekuatan lingkungan; 5) motivasi, dengan memberikan dorongan, apresiasi terhadap pekerjaan bawahan, memberikan pengakuan dan perhatian individual dari atasan dapat 
mempunyai pengaruh positif terhadap motivasi bawahan; 6) kemampuan intelektual, kompetensi bergantung pada pemikiran kognitif seperti pemikiran konseptual dan pemikiran analitis. Faktor pengalaman dapat meningkatkan kecakapan dalam kompetensi (Sudarmanto, 2009).

\section{Manfaat Penggunaan Kompetensi Sumber Daya Manusia (SDM)}

Manfaat yang dapat diperoleh jika suatu instansi memperhatikan kompetensi SDM yaitu: 1) memperjelas standar kerja dan harapan yang ingin dicapai; 2) alat seleksi karyawan; 3) memaksimalkan produktivitas; 4) dasar untuk pengembangan sistem remunerasi; 5) memudahkan adaptasi terhadap perubahan; 6) menyelaraskan prilaku kerja dengan nilai-nilai organisasi (Nuryanto et al., 2017).

Pengendalian intern merupakan proses yang integral pada tindakan dan kegiatan yang dilakukan secara terus menerus oleh pimpinan dan seluruh pegawai untuk memberikan keyakinan memadai atas tercapainya tujuan organisasi melalui kegiatan yang efektif dan efisien, keandalan pelaporan keuangan, pengemanan aset negara dan ketaatan terhadap peraturan perundang-undangan (Hery, 2015). Dalam kaitannya dengan efektivitas penyusunan laporan keuangan maka baik buruknya implementasi sistem pengendalian iternal dapat mempengaruhi kualitas laporan keuangan pemerintah daerah yang akan dihasilkan.

\section{Tujuan Pengendalian Intern}

Pengendalian intern bertujuan untuk memberikan keyakinan yang memadai guna tercapainya efektivitas dan efisiensi pencapaian tujuan penyelenggaraan pemerintah negaraa, keandalan pelaporan keuangan, pengamanan aset negara dan ketaatan terhadap peraturan perundang-undangan (Dera, 2016).

\section{Unsur-Unsur Sistem Pengendalian Internal Pemerintah}

Berdasarkan Peraturan Pemerintah Nomor 60 Tahun 2008, sistem pengendalian internal pemerintah terdiri dari: 1) lingkungan pengendalian, pimpinan instansi pemerintah wajib menciptakan dan memelihara lingkungan pengendalian yang menimbulkan perilaku positif dan kondusif untuk penerapan sistem pengendalian internal dalam lingkungan kerjanya; 2) penilaian resiko, pimpinan instansi pemerintah 
dapat menetapkan tujuan instansi pemerintah dan tujuan pada tingkatan kegiatan dengan berpedoman pada peraturan perundang-undangan; 3) kegiatan pengendalian, pimpinan instansi pemerintah wajib menyelenggarakan kegiatan pengendalian sesuai ukuran, kompleksitas, dan sifat dari tugas dan fungsi instansi pemerintah yang bersangkutan; informasi dan komunikasi, pimpinan instansi pemerintah wajib mengidentifikasi, mencatat dan mengkomunikasi informasi dalam bentuk dan waktu yang tepat

Selanjutnya, 4) pemantauan pengendalian internal, pimpinan instansi pemerintah wajib melakukan pemantauan sistem pengendalian internal melalui evaluasi terpisah, tindak lanjut rekomendasi hasil audit dan temuan lainnya. LKPD disusun untuk menyediakan informasi yang relevan mengenai posisi keuangan dan seluruh transaksi yang dilakukan oleh pemerintah daerah selama satu periode pelaporan.

\section{Tujuan Laporan Keuangan}

Menurut Ikatan Akuntan Indonesia (2009) laporan keuangan berperan dalam menyajikan informasi mengenai posisi keuangan, realisasi anggaran, saldo anggaran lebih, arus kas, hasil operasi perubahan ekuitas suatu entitas pelaporan yang bermanfaat yang bagi pengguna dalam membuat dan mengevaluasi keputusan mengenai alokasi sumber daya. Laporan keuangan yang baik harus memenuhi karakteristik berikut ini: 1) relevan, dikatakan relevan apabila informasi yang termuat di dalamnya dapat mempengaruhi keputusan pengguna dengan membantu mereka mengevaluasi peristiwa masa lalu atau masa kini dan memprediksi masa depan serta menegaskan atau mengoreksi hasil evaluasi mereka di masa lalu; 2) andal, informasi dalam laporan keuangan bebas dari pengertian yang menyesatkan dan kesalahan material, menyajikan setiap fakta secara jujur serta dapat diverifikasi.

Selanjutnya, 3) dapat dibandingkan, informasi yang termuat dalam laporan akan lebih berguna jika dapat dibandingkan dengan laporan keuangan periode sebelumnya aau laporan keuangan entitas laporan lain umunya. Perbandingan dapat dilakukan secara internal maupun eksternal; 4) dapat dipahami, informasi yang disajikan dalam laporan keuangan dapat dipahami oleh pengguna dan dinyatakan dalam bentuk serta istilah yang disesuaikan dengan batas pemahaman para pengguna. Untuk itu pengguna diasumsikan memiliki pengentahuan yang memadai atas kegiatan dan lingkungan operasi entitas 
pelaporan serta adanya kemauan pengguna untuk mempelajari informasi yang dimaksud.

Menurut Moeheriono (2010) karakteristik yang mendasari seseorang berkaitan dengan efektivitas kinerja individu dalam pekerjaannya atau karakterisitik dasar indiviu yang memiliki hubungan kausat atau sebagai sebab-akibat dengan kriteria yang dijadikan acuan, efektif atau berkinerja prima atau superior di tempat kerja atau pada situasi tertentu.

\section{METODE PENELITIAN}

Metode yang digunakan pada penelitian ini yaitu metode survei melalui kuesioner sebagai alat penelitian yang disebar kepada 50 (responden) pegawai Badan Pengelola Keuangan dan Aset Daerah (BPKAD) Pemerintah Daerah Kabupaten Bondowoso. Penelitian dilakukan di BPKAD Bondowoso, Jl. Letjen Suprapto No. 68 Bondowoso. Metode pengambilan sampel dilakukan dengan teknik sampling jenuh (sensus) atau teknik penentuan sampel bila semua anggota populasi digunakan sebagai sampel. Hal ini dilakukan karena jumlah populasi relatif kecil dari 100 orang, maka semua populasi dalam penelitian ini dijadikan sebagai sampel yaitu sebanyak 50 orang. Pengujian dilakukan menggunakan uji validitas dan reliabilitas. Jenis penelitian ini berupa penelitian kualitatif, maka data dapat diperoleh dari hasil observasi, wawancara dan dokumentasi.

\section{HASIL PENELITIAN}

\section{Statistik Deskriptif Responden}

Responden dalam penelitian ini adlah seluruh pegawai Badan Pengelolaan Keuangan dan Aset Daerah Kabupaten Bondowoso.

Tabel 1.

Distribusi Karakteristik Responden

Pegawai Badan Pengelolaan Keuangan dan Aset Daerah Kabupaten Bondowoso

Berdasarkan Jenis Kelamin

\begin{tabular}{cccccc}
\hline & Jenis kelamin & Frequency & Percent & Valid Percent & Cumulative Percent \\
\hline \multirow{2}{*}{ Valid } & L & 29 & 58 & 58 & 58 \\
& $\mathrm{P}$ & 21 & 42 & 42 & 100 \\
\hline \multicolumn{2}{c}{ Total } & 50 & 100 & 100 & \\
\hline
\end{tabular}


Data tabel 1 menunjukkan bahwa sebagaian besar responden yang menjawab kuesioner adalah responden laki-laki yang berjumlah 29 responden dengan presentase sebanyak 58\% dan sisanya adalah responden dengan jenis kelamin perempuan sebanyak 21 dengan persentase (42).

\section{Variabel Presentase Kompetensi SDM $\left(\mathrm{X}_{1}\right)$}

Berdasarkan hasil pengujian statistik, maka penilaian responden terhadap Kompetensi SDM adalah sebagai berikut:

Tabel 2.

Deskriptif Penilaian Responden Terhadap Kompetensi SDM $\left(\mathrm{X}_{1}\right)$

\begin{tabular}{|c|c|c|c|c|c|c|c|c|}
\hline Indikator & Pernyataan & $\mathrm{F} / \%$ & SS & $\mathbf{S}$ & $\mathbf{N}$ & TS & STS & Total \\
\hline $\begin{array}{c}\text { Keterampilan } \\
\mathrm{X}_{1.1}\end{array}$ & $\begin{array}{l}\text { Saya memiliki keterampilan } \\
\text { berbicara di depan umum } \\
\text { dan menulis yang akan } \\
\text { meningkatkan kecakapan } \\
\text { saya dalam kompetensi } \\
\text { tentang perhatian terhadap } \\
\text { komunikasi. }\end{array}$ & $\%$ & 14,0 & 62,0 & 22,0 & 2,0 & 0 & 100,0 \\
\hline $\begin{array}{c}\text { Pengalaman } \\
\mathrm{X}_{1.2}\end{array}$ & $\begin{array}{l}\text { Saya memiliki pengalaman } \\
\text { mengorganisasikan orang, } \\
\text { komunikasi di hadapan } \\
\text { kelompok dan } \\
\text { menyelesaikan masalah di } \\
\text { organisasi besar dan } \\
\text { kompleks. }\end{array}$ & 16,0 & 52,0 & 32,0 & 0 & $\overline{0}$ & 14,0 & 100,0 \\
\hline $\begin{array}{c}\text { Karakteristik } \\
\text { Pribadi } \\
\mathrm{X}_{1.3}\end{array}$ & $\begin{array}{l}\text { Saya merasa mampu } \\
\text { penyelesaian konflik, } \\
\text { menunjukkan kepedulian } \\
\text { interpersonal, kemampuan } \\
\text { bekerja dalam tim, } \\
\text { memberikan pengaruh dan } \\
\text { membangun hubungan }\end{array}$ & 12,0 & 58,0 & 12,0 & 2,0 & 2,0 & 14,0 & 100,0 \\
\hline Motivasi $_{1.4}$ & $\begin{array}{l}\text { Saya merasa membutuhkan } \\
\text { motivasi berupa dorongan, } \\
\text { apresiasi terhadap } \\
\text { pekerjaan bawahan, } \\
\text { memberikan pengakuan dan } \\
\text { perhatian individual dari } \\
\text { atasan }\end{array}$ & 10,0 & 62,0 & 28,0 & 0 & 0 & 14,0 & 100,0 \\
\hline $\begin{array}{c}\text { Kemampuan } \\
\text { Intelektual } \\
\mathrm{X}_{1.5}\end{array}$ & $\begin{array}{l}\text { Saya merasa memiliki } \\
\text { pemikiran kognitif seperti } \\
\text { pemikiran konseptual dan } \\
\text { pemikiran analitis. }\end{array}$ & 18,0 & 70,0 & 28,0 & 0 & 0 & 14,0 & 100,0 \\
\hline
\end{tabular}

Berdasarkan data tabel 2, ditemukan bahwa dari segi keterampilan, responden paling banyak menyatakan setuju terhadap pernyataan dengan persentase sebesar $62 \%$. Pada indikator pengalaman, 52\% responden menyatakan sangat setuju dengan 
pernyataan. Selanjutnya pada karakteristik pribadi, 58\% renponden menyatakan sangat setuju terhadap pernyataan. Adapun pada motivasi, responden terbanyak menyatakan sangat setuju terhadap pernyataan dengan persentase sebesar $62 \%$. Kemudian pada kemampuan intelektual, $70 \%$ responden menyatakan sangat setuju terhadap pernyataan.

\section{Variabel Presentase Penerapan Sistem Pengendalian Intern Pemerintah $\left(\mathbf{X}_{2}\right)$}

Berdasarkan hasil pengujian statistik, maka hasil penelitian responden terhadap penerapan sistem pengendalian intern pemerintah adalah sebagai berikut:

Tabel 3.

Deskriptif Penilaian Responden terhadap Penerapan Sistem Pengendalian Intern Pemerintah $\left(\mathbf{X}_{2}\right)$

\begin{tabular}{|c|c|c|c|c|c|c|c|c|}
\hline Indikator & Pernyataan & F/\% & SS & $\mathbf{S}$ & $\mathbf{N}$ & TS & STS & Total \\
\hline $\begin{array}{l}\text { Lingkungan } \\
\text { pengendalian } \\
\mathrm{X}_{2.1}\end{array}$ & $\begin{array}{lr}\text { Saya merasa } & \text { Pimpinan } \\
\text { Instansi Pemerintah telah } \\
\text { menciptakan r } & \text { dan } \\
\text { memelihara } & \text { lingkungan } \\
\text { pengendalian } & \text { yang } \\
\text { menimbulkan } & \text { perilaku } \\
\text { positif dan kondusif. }\end{array}$ & $\%$ & 28,0 & 50,0 & 22,0 & 0 & 0 & 100,0 \\
\hline $\begin{array}{l}\text { Penilaian } \\
\text { Resiko } X_{2.2}\end{array}$ & $\begin{array}{l}\text { Saya merasa pimpinan OPD } \\
\text { memahami tentang penilaian } \\
\text { resiko. }\end{array}$ & 16,0 & 58,0 & 22,0 & 4,0 & 0 & 14,0 & 100,0 \\
\hline $\begin{array}{c}\text { Kegiatan } \\
\text { Pengendalian } \\
\mathrm{X}_{2.3}\end{array}$ & $\begin{array}{l}\text { Saya merasa Pimpinan } \\
\text { Instansi Pemerintah telah } \\
\text { menyelenggarakan kegiatan } \\
\text { pengendalian sesuai dengan } \\
\text { ukuran, kompleksitas, dan } \\
\text { sifat dari tugas dan fungsi } \\
\text { Instansi Pemerintah yang } \\
\text { bersangkutan. }\end{array}$ & 8,0 & 42,0 & 44,0 & 6,0 & 0 & 14,0 & 100,0 \\
\hline $\begin{array}{l}\text { Informasi dan } \\
\text { Komunikasi } \\
\mathrm{X}_{2.4}\end{array}$ & $\begin{array}{l}\text { Saya merasa Pimpinan } \\
\text { Instansi Pemerintah telah } \\
\text { mengidentifikasi, mencatat, } \\
\text { dan mengkomunikasikan } \\
\text { informasi dalam bentuk dan } \\
\text { waktu yang tepat. }\end{array}$ & 8,0 & 62,0 & 28,0 & 2,0 & 0 & 14,0 & $\begin{array}{c}50 \\
100,0\end{array}$ \\
\hline $\begin{array}{c}\text { Pemantauan } \\
\mathrm{X}_{2.5}\end{array}$ & $\begin{array}{lr}\text { Pimpinan } & \text { Instansi } \\
\text { Pemerintah telah melakukan } \\
\text { pemantauan }\end{array}$ & 18,0 & 28,0 & 50,0 & 18,0 & 0 & 14,0 & $\begin{array}{c}50 \\
100,0\end{array}$ \\
\hline
\end{tabular}

Berdasarkan tabel 3, diketahui bahwa sebanyak 50\% responden menyatakan setuju pada pernyataan indikator $\mathrm{X}_{2.1}$ dan sebanyak $58 \%$ responden sangat setuju 
terhadap pernyataan indikator $X_{2.2}$. Adapun pada $X_{2.3}$, sebanyak $44 \%$ responden menyatakan setuju terhadap pernyataan dan 62\% menyatakan sangat setuju pada pernyataan indikator $\mathrm{X}_{2.4}$. Kemudian pada $\mathrm{X}_{2.5}$, sebanyak $50 \%$ responden menyatakan setuju terhadap pernyataan.

\section{Variabel Presentase Kualitas Laporan Keuangan Pemerintah Daerah Kabupaten}

\section{Bondowoso (Y)}

Berdasarkan hasil pengujian statistik, maka hasil penilaian responden terhadap kualitas laporan keuangan pemerintah daerah adalah sebagai berikut:

Tabel 4.

Deskriptif Penilaian Responden terhadap Kualitas Laporan Keuangan Pemerintah Daerah (Y)

\begin{tabular}{|c|c|c|c|c|c|c|c|c|}
\hline Indikator & Pernyataan & F/\% & SS & $\mathbf{S}$ & $\mathbf{N}$ & TS & STS & Total \\
\hline $\begin{array}{c}\text { Relevan } \\
\mathrm{Y}_{1.1}\end{array}$ & $\begin{array}{l}\text { Saya merasa informasi yang } \\
\text { termuat di laporan keuangan } \\
\text { dapat mempengaruhi } \\
\text { keputusan pengguna dengan } \\
\text { membantu mereka } \\
\text { mengevaluasi peristiwa } \\
\text { masa lalu atau masa kini, } \\
\text { dan memprediksi masa } \\
\text { depan, serta menegaskan } \\
\text { atau mengoreksi hasil } \\
\text { evaluasi mereka di masa } \\
\text { lalu. }\end{array}$ & $\%$ & 14,0 & 64,0 & 22,0 & 0 & 0 & 100,0 \\
\hline $\begin{array}{c}\text { Andal } \\
\mathrm{Y}_{1.2}\end{array}$ & $\begin{array}{l}\text { Saya merasa laporan } \\
\text { keuangan bebas dari } \\
\text { pengertian } \\
\text { menyesatkan dan kesalahan } \\
\text { material, menyajikan setiap } \\
\text { fakta secara jujur, serta dapat } \\
\text { diverifikasi. }\end{array}$ & $\%$ & 12,0 & 50,0 & 36,0 & 2,0 & 0 & 100,0 \\
\hline $\begin{array}{c}\text { Dapat } \\
\text { dibandingkan } \\
\mathrm{Y}_{1.3}\end{array}$ & $\begin{array}{lr}\text { Saya merasa } & \begin{array}{r}\text { laporan } \\
\text { dapat }\end{array} \\
\text { keuangan } & \text { dengan } \\
\text { dibandingkan } & \text { periode } \\
\text { laporan keuangan } & \text { laporan } \\
\text { sebelumnya atau } & \text { langan entitas pelaporan } \\
\text { keuangan } & \\
\text { lain umumnya } & \end{array}$ & $\%$ & 10,0 & 42,0 & 46,0 & 2,0 & 0 & $\begin{array}{c}50 \\
100,0\end{array}$ \\
\hline $\begin{array}{c}\text { Dapat } \\
\text { dipahami } \\
\mathrm{Y}_{1.4}\end{array}$ & \begin{tabular}{lr}
\multicolumn{3}{l}{ Saya merasa Informasi yang } \\
disajikan dalam laporan \\
keuangan dapat dipahami \\
oleh pengguna dan \\
dinyatakan dalam bentuk \\
serta istilah & yang \\
disesuaikan dengan batas \\
pemahaman para pengguna
\end{tabular} & $\begin{array}{l}\mathrm{F} \\
\%\end{array}$ & $\begin{array}{c}3 \\
6,0\end{array}$ & $\begin{array}{r}30 \\
60,0\end{array}$ & $\begin{array}{c}13 \\
26,0\end{array}$ & 6,0 & 0 & $\begin{array}{c}50 \\
100,0\end{array}$ \\
\hline
\end{tabular}


Berdasarkan tabel 4, diketahui bahwa sebanyak $64 \%$ responden menyatakan setuju pada pernyataan indikator $\mathrm{Y}_{1.1}$ dan sebanyak $50 \%$ responden setuju terhadap pernyataan indikator $Y_{1.2}$. Adapun pada $Y_{1.3}$, sebanyak $46 \%$ responden menyatakan netral terhadap pernyataan dan $60 \%$ menyatakan setuju pada pernyataan indikator $\mathrm{Y}_{1.4}$.

\section{Pengujian Validitas}

Item kuesioner dinyatakan valid apabila nilai r-hitung > r-tabel (n-2). Pengujian validitas selengkapnya berikut ini:

Tabel 5.

Hasil Pengujian Validitas

\begin{tabular}{cccc}
\hline Variabel & r-Hitung & r-Tabel & Keterangan \\
\hline $\mathrm{X}_{1.1}$ & 0,875 & 0,3338 & Valid \\
$\mathrm{X}_{1.2}$ & 0,705 & 0,3338 & Valid \\
$\mathrm{X}_{1.3}$ & 0,846 & 0,3338 & Valid \\
$\mathrm{X}_{1.4}$ & 0,830 & 0,3338 & Valid \\
$\mathrm{X}_{1.5}$ & 0,584 & 0,3338 & Valid \\
$\mathrm{X}_{2.1}$ & 0,659 & 0,3338 & Valid \\
$\mathrm{X}_{2.2}$ & 0,666 & 0,3338 & Valid \\
$\mathrm{X}_{2.3}$ & 0,768 & 0,3338 & Valid \\
$\mathrm{X}_{2.4}$ & 0,842 & 0,3338 & Valid \\
$\mathrm{X}_{2.5}$ & 0,663 & 0,3338 & Valid \\
$\mathrm{Y}_{1.1}$ & 0,557 & 0,3338 & Valid \\
$\mathrm{Y}_{1.2}$ & 0,765 & 0,3338 & Valid \\
$\mathrm{Y}_{1.3}$ & 0,841 & 0,3338 & Valid \\
$\mathrm{Y}_{1.4}$ & 0,768 & 0,3338 & Valid \\
\hline
\end{tabular}

Hasil pengujian validitas menunjukkan semua indikator dalam penelitian ini memiliki nilai r-hitung yang lebih besar dari pada r-tabel. Hal ini menunjukkan bahwa setiap indikator dalam penelitian ini adalah valid.

\section{Pengujian Reliabilitas}

\section{Pengujian Reliabilitas dengan Menggunakan Rumus Alpha}

\section{Tabel 6.}

Hasil Pengujian Reliabilitas

\begin{tabular}{ccc}
\hline Variabel & Alpha & Keterangan \\
\hline Kompetensi SDM $\left(\mathrm{X}_{1}\right)$ & 0,830 & Reliable \\
Penerapan Pengendalian Intern Pemerintah $\left(\mathrm{X}_{2}\right)$ & 0,759 & Reliable \\
Kualitas Laporan Keuangan Pemereintah Daerah & 0,722 & Reliable \\
\hline
\end{tabular}


Berdasarkan table di atas menunjukkan bahwa semua variabel mempunyai koefisien alpha yang cukup besar yaitu diatas 0.60 sehingga semua konsep pengukur masing-masing varibel dari kuesioner adalah reliable.

\section{Analisis Persamaan regresi Linier Berganda}

\section{Tabel 7.}

Hasil Estimasi Regresi

\begin{tabular}{cccccccr}
\hline \multicolumn{9}{c}{$\begin{array}{c}\text { Coefficients } \\
\text { Unstandardized } \\
\text { Coefficients }\end{array}$} & $\begin{array}{c}\text { Standardized } \\
\text { Coefficients }\end{array}$ & & & \multicolumn{2}{c}{$\begin{array}{c}\text { Collinearity } \\
\text { Statistics }\end{array}$} \\
\hline Model & B & Std. Error & Beta & t & Sig. & Tolerance & VIF \\
\hline 1 (Constant) & $-4.627 \mathrm{E}-16$ & .087 & & .000 & 1.000 & & \\
$\mathrm{X}_{1}$ & .389 & .151 & .389 & 2.584 & .013 & .341 & 2.935 \\
$\mathrm{X}_{2}$ & .449 & .151 & .449 & 2.979 & .005 & .341 & 2.935 \\
\hline
\end{tabular}

Berikut ini merupakan bentuk persamaan yang diperoleh berdasarkan hasil analisis tabel 7:

$$
\mathrm{Y}=-4.627 \mathrm{E}-16+0,389 \mathrm{X}_{1}+0,449 \mathrm{X}_{2}+e
$$

\section{Uji t (Uji Hipotesis Secara Parsial)}

Tabel 8.

Hasil Uji t Secara Parsial

\begin{tabular}{cccc}
\hline Variabel Bebas & t-Hitung & t-Tabel & Sig. t \\
\hline Kompetensi SDM $\left(\mathrm{X}_{1}\right)$ & 2,584 & 1,67866 & 0.013 \\
Penerapan Sistem Pengendalian Intern Pemerintah $\left(\mathrm{X}_{2}\right)$ & 2,979 & 1,67866 & 0.013 \\
\hline
\end{tabular}

Berdasarkan tabel 8, terlihat bahwa hasil pengujian $\mathrm{X}_{1}$ menunjukkan nilai $\mathrm{t}$ hitung sebesar 2,584 dengan taraf signifikansi 0,013. Taraf signifikansi tersebut lebih kecil dari 0,05. Dengan demikian dapat berarti bahwa kompetensi SDM mempunyai pengaruh positif terhadap kualitas laporan keuangan pemerintah daerah.

Selain itu, hasil pengujian $X_{2}$ menunjukkan bahwa nilai t hitung sebesar 2,979 dengan taraf signifikansi 0,005. Taraf signifikansi tersebut lebih kecil dari 0,05. Dengan demikian berarti bahwa penerapan sistem pengendalian intern pemerintah mempunyai pengaruh positif terhadap kualitas laporan keuangan pemerintah daerah. 


\section{Uji F (Pengujian Hipotesis Secara Simultan)}

Tabel 9.

Hasil Analisis Regresi Secara Simultan

\begin{tabular}{cccccc}
\hline \multicolumn{7}{c}{ ANOVA $^{\mathbf{b}}$} & F & Sig. \\
\hline Model & Sum of Squares & Df & Mean Square & $.000^{\mathbf{a}}$ \\
\hline 1 Regression & 31.193 & 2 & 15.597 & 41.167 & \\
Residual & 17.807 & 47 & .379 & & \\
\hline Total & $\mathbf{4 9 . 0 0 0}$ & $\mathbf{4 9}$ & & & \\
\hline a. $\quad$ Predictors: (Constant), X2, X1 & & & \\
b. Dependent Variable: $\mathrm{Y}$ & & & & \\
\hline
\end{tabular}

Pengujian pengaruh variabel bebas secara bersama-sama terhadap variabel terikatnya dilakukan dengan menggunakan uji F. Hasil perhitungan statistik menunjukkan nilai F hitung = 41.167. Dengan menggunakan batas signifikansi 0,05, maka diperoleh nilai signifikansi tersebut lebih kecil dari 0,05. Hal ini berarti bahwa secara simultan variabel kompetensi SDM dan penerapan sistem pengendalian intern pemerintah mempunyai pengaruh terhadap kualitas laporan keuangan pemerintah daerah.

\section{Koefisien Determinasi (R)}

Koefisien determinasi merupakan besaran yang menunjukkan besarnya variasi variabel dependen yang dapat dijelaskan oleh variabel independennya. Dengan kata lain, koefisien determinasi ini digunakan untuk mengukur seberapa jauh variablevariabel bebas dalam menerangkan variabel terikatnya. Nilai koefisien determinasi ditentukan dengan nilai adjusted $R$ square.

Tabel 10.

Koefisien Determinasi

\begin{tabular}{lccccc}
\hline \multicolumn{6}{c}{ Model Summary } \\
\hline Model & $\mathbf{R}$ & R Square & $\begin{array}{c}\text { Adjusted } \mathbf{R} \\
\text { Square }\end{array}$ & $\begin{array}{c}\text { Std. Error of } \\
\text { the Estimate }\end{array}$ & $\begin{array}{c}\text { Durbin- } \\
\text { Watson }\end{array}$ \\
\hline 1 & $.798^{\mathrm{a}}$ & .637 & .621 & .615 & 2.030 \\
\hline a. & $\begin{array}{l}\text { Predictors: } \\
\text { b. }\end{array}$ & Depenstant), $\mathrm{X} 2, \mathrm{X} 1$ & & \\
\hline
\end{tabular}

Hasil perhitungan regresi dapat diketahui bahwa koefisien determinasi (adjusted $R 2$ ) yang diperoleh sebesar 0,621 . Hal ini berarti $62,1 \%$ variasi variabel kualitas laporan keuangan pemerintah daerah dapat dijelaskan oleh variabel kompetensi SDM 
dan penerapan sistem pengendalian intern pemerintah sedangkan sisanya sebesar 37,9\% diterangkan oleh variabel lain yang tidak diajukan dalam penelitian ini.

\section{Uji Asumsi Klasik}

Tabel 11.

Hasil Uji Multikolinieritas

\begin{tabular}{ccc}
\hline Variabel Bebas & Toleransi & VIF \\
\hline Kompetensi SDM $\left(\mathrm{X}_{1}\right)$ & 0,341 & 2.935 \\
Penerapan Sistem Pengendalian Intern Pemerintah $\left(\mathrm{X}_{2}\right)$ & 0,341 & 2.935 \\
\hline
\end{tabular}

Dari tabel tersebut menunjukkan bahwa nilai VIF semua variabel bebas dalam penelitian ini lebih kecil dari 10 sedangkan nilai toleransi semua variabel bebas lebih dari $10 \%$ yang berarti tidak terjadi korelasi antar variabel bebas yang nilainya lebih dari 90\%, dengan demikian dapat disimpulkan bahwa tidak terdapat gejala multikolinieritas antar variabel bebas dalam model regresi.

\section{PEMBAHASAN}

Hasil penelitian menunjukkan bahwa secara statistik kompetensi SDM berpengaruh positif terhadap kualitas laporan keuangan pemerintah daerah. Hal ini disebabkan karena adanya aspek-aspek yang berkaitan dengan Kompetensi SDM yang telah memberikan dampak positif terhadap kualitas laporan keuangan pemerintah daerah kecamatan kota Bondowoso. Selain itu, hasil penelitian juga menunjukkan bahwa terdapat pengaruh antara penerapan sistem pengendalian intern pemerintah terhadap kualitas laporan keuangan pemerintah daerah.

Kompetensi SDM dan penerapan sistem pengendalian intern pemerintah juga berpengaruh positif terhadap kualitas laporan keuangan pemerintah daerah. Hal ini menunjukkan bahwa terdapat pengaruh antara variabel secara simultan terhadap kualitas laporan keuangan pemerintah daerah kecamatan kota Bondowoso. Hasil yang sama juga ditemukan oleh Yaqin \& Jatmiko (2018) bahwa kompetensi sumber daya manusia berpengaruh positif terhadap kualitas laporan keuangan pemerintah, diketahui juga bahwa standar akuntansi pemerintah berpengaruh positif terhadap kualitas laporan keuangan pemerintah. Begitu juga dengan hasil analisis sistem pengendalian internal pemerintah yang berpengaruh positif terhadap kualitas laporan keuangan pemerintah. 
Menurut Rusmanto (2008) para pengguna laporan keuangan yaitu: 1) pemegang saham, digunakan untuk mengetahui kondisi keuangan perusahaan, aset, utang, modal, hasil, laba, prestasi perusahaan dalam pengelolaan manajemen yang diberikan amanah, jumlah deviden yang diterima, jumlah pendapatan persaham, jumlah laba yang ditahan, perkembangan perusahaan dari waktu kewaktu, perbandingan dengan usaha sejenis dan perusahaan lainnya; 2) investor, berguna untuk melihat kemungkinan potensial keuntungan yang akan diperoleh dari perusahaan yang dilaporkan; 3) pemberi dana (kreditur), untuk mengetahui informasi tentang situasi dan kondisi perusahaan baik yang sudah diberi pinjaman maupun yang akan diberi pinjaman; 4) analis pasar modal, untuk melakukan analisa tajam dan lengkap terhadap laporan keuangan perusahaan go public maupun yang berpotensi memasuki pasar modal; 5) manajer, untuk mengetahui situasi ekonomi perusahaan yang dipimpinnya.

Selanjutnya yaitu, 6) karyawan dan serikat pekerja, untuk mengetahui kondisi keuangan perusahaan; 7) instansi pajak, laporan keuangan sebagai dasar menentukan kebenaran perhitungan pajak, pemotongan pajak, restitusi dan juga untuk dasar penindakan; 8) peneliti/akademisi/lembaga peringkat, bagi peneliti maupun akademisi laporan digunakan sebagai data primer dalam melakukan penelitian terhadap topik tertentu yang berkaitan dengan laporan keuangan atau perusahaan. Laporan keuangan menjadi bahan dasar yang diolah dalam mengambil keputusan dari suatu hipotesa atau penelitian yang dilakukan.

\section{SIMPULAN}

Hasil penelitian membuktikan bahwa kompetensi SDM berpengaruh positif dan signifikan terhadap kualitas laporan keuangan pemerintah daerah. Selain itu, hasil penelitian juga menunjukan bahwa penerapan sistem pengendalian intern pemerintah berpengaruh positif dan signifikan terhadap kualitas laporan keuangan pemerintah daerah. 


\section{DAFTAR PUSTAKA}

Dera, A. P., Sondakh, J. J., \& Warongan, J. D. L. (2016). Analisis Efektivitas Sistem Pengendalian Internal Piutang dan Kerugian Piutang Tak Tertagih pada PT. Surya Wenang Indah Manado. Jurnal EMBA, 4(1), 1498-1508

Halim, A. (2012). Akuntansi Sektor Publik Akuntansi Keuangan Daerah. Jakarta: Salemba Empat

Hery, H. (2015). Akuntansi Dasar 1 dan 2, Cetakan Ketiga. Jakarta: PT Gramedia

Ikatan Akuntansi Indonesia. (2009). Standar Akuntansi Keuangan. Jakarta: Salemba Empat

Mardiasmo, M. (2009). Akuntansi Sektor Publik. Yogyakarta: Andi Yogyakarta

Marwansyah, M. (2012). Manajemen Sumber Daya Manusia, Edisi Kedua. Bandung: Alfabeta

Nuryanto, N., Enggok, M. S., \& Abdurrahman, A. (2017). Pengaruh Kompetensi terhadap Produktivitas Kerja Pegawai Kantor Unit Penyelenggara Pelabuhan Kelas III Satui. Administraus-Jurnal Ilmu Administrasi dan Manajemen, 1(1), 83-96

Peraturan Pemerintah Nomor 60. (2008). Sistem Pengendalian Intern Pemerintah. http://www.bpkp.go.id/public/upload/unit/sakd/files/PP60Tahun2008_SPIP

Presiden Republik Indonesia. (2004). Undang-Undang Republik Indonesia Nomor 25 Tahun 2004 tentang Sistem Perencanaan Pembangunan Nasional. Diakses dari https://bapenda.jabarprov.go.id/

Rusmanto, R. (2008). Pengaruh Karakteristik Kualitatif Laporan Keuangan terhadap Penggunaannya dalam Pengambilan Keputusan Kredit Bank Umum di Banjarmasin. Ekuitas 12(1), 53-73

Sudarmanto, S. (2009). Kinerja dan Pengembangan Kompetensi SDM. Yogyakarta: Pustaka Pelajar

Wati, K. D., Herawati, N. T., \& Sinarwati, N. K. (2014). Pengaruh Kompetensi SDM, Penerapan SAP dan Sistem Akuntansi Keuangan Daerah terhadap Kualitas Laporan Keuangan Daerah. e-Journal S1 Ak Universitas Pendidikan Ganesha, 2(1), 1-11

Yaqin, A., \& Jatmiko, B. (2018). Kontribusi Kompetensi Sumber Daya Manusia, Standar Akuntansi Pemerintah dan Sistem Pengendalian Internal Pemerintah terhadap Kualitas Laporan Keuangan Pemerintah: Studi Kasus pada Satuan Kerja Perangkat Daerah Kab. Biak Numfor. Reviu Akuntansi dan Bisnis Indonesia, 2(1), 1-10 